\title{
DEVELOPMENT OF METHODOLOGICAL FRAMEWORK FOR SETTING THE DRUG STOCK IN PHARMACY DISTRIBUTION
}

\author{
O.V.Posylkina, V.G.Kotlarova, Yu.Ye.Novitska \\ National University of Pharmacy
}

Key words: personalization; logistic service; customer; social responsibility

The article has proven that the use of the traditional approach to setting the drug stock level in pharmacy distribution can lead to determination of the level of money immobilized for stock making and does not take into account the needs, expectations and peculiarities of customers, as well as different social significance of specific pharmacological groups of drugs. The methodology making basis for the existing approach to the stock setting does not meet the current requirements to the proper level of the customer service. Thus, the need to improve the approach to setting the medication stock level in pharmacy distribution has arisen. The social responsibility of pharmaceutical business foresees the use of both economic and social parameters in drug stock setting. In social terms, the stock setting task is to determine a list and volume of medications to be available at a warehouse to meet the customers' needs. The stock should have the following groups: quarantine-prevention, current, buffer and reserve. The volume of daily sale of medications is calculated taking into account the volume of sale: in case of the periods with no seasonal demand fluctuations taking into account the trend of changes in frequency of prescribing drugs in nosology; the reserve stock of medications in case of the unforeseen demand fluctuations; in the period of seasonal demand fluctuations. It has been proven that it is reasonable to substantiate the stock level in pharmacy distribution using the ABC-VEN analysis. Meeting the customer's needs is the main task of any pharmacy company, including wholesalers. So, it needs to make a stock of pharmaceuticals neither too small - since the company would not be able to maintain the sales and respond flexibly to demand fluctuations, nor too large - it may cause the increase in storage costs, turnover decrease, 'freezing' of money invested into purchase. Setting of the stock rate is used to determine the necessary stock level.

The necessity of stock setting to improve the stock management is explained in the works of Alesynska T., Barkalov S., Hadzhynskyi O., Kalchenko A., Kindii M., Krykavskyi Ye., Mate T., Novikov O., Oklander M., etc. The analysis of their research has shown that the stock setting methodology is a product of a daily stock consumption by the stock level. The same approach is traditionally used when setting the stock of medications in pharmacy distribution. These issues are dealt with in the works of Hromovyk B., Gudzenko O., Mnushko Z., Nemchenko A., Tolochko V., Trokhymchuk V., Barnatovych S., Dorokhova L., Gorbunova O., Kutsenko S. and others.

\section{Experimental Part}

Traditional approaches to setting the drug stock level in pharmacy distribution have a general nature being more characteristic of the level of money immobilized for stock making, and without taking into account the needs, expectations and peculiarities of customers. The methodology making basis for the existing approach to the stock setting does not meet the current requirements to the proper level of the customer service. Thus, the need to improve the approach to setting the medication stock level in pharmacy distribution has arisen.

The aim of this article is to develop the methodological framework for setting the stock of medications in pharmacy distribution based on the differentiation of the customer logistic service.

\section{Materials and Methods}

The comparative analysis methods, statistical and analytical method of stock setting were used in this research.

\section{Results and Discussion}

The social responsibility of pharmaceutical business foresees the use of both economic and social parameters in drug stock setting.

The cost-efficiency principle suggests reaching of the rational (optimal) cost-income ratio in the company's performance. The wholesale pharmaceutical companies (WPC) implement this principle by choosing the most profitable medications and health products for sale or the products that have the highest cost contribution rate.

The social responsibility principle means the company's commitment to its product or service. The intense competition at the pharmaceutical distribution market requires distributors to develop individual logistic solutions to meet the customers' needs. Therefore, the WPC must have socially important medications regardless of their profitability.

In economic (financial) terms, the stock setting task is to determine an amount of money that may be immobilized from the company's turnover. In social terms, the stock setting task is to determine a list and volume of medications to be available at a warehouse to meet the customers' needs. 


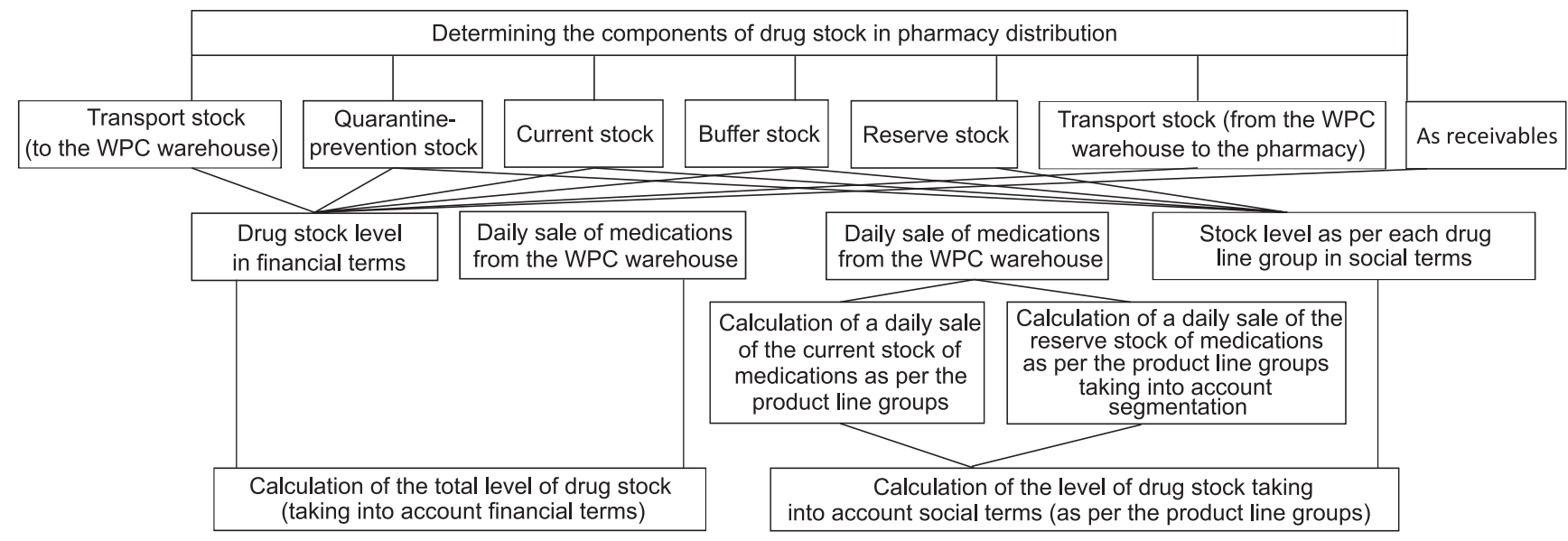

Fig. The scheme proposed for calculation of drug stock in pharmacy distribution taking into account the financial and social aspects.

The level with these two parameters (economic and social) is calculated with the known formula: $\mathrm{H}=\mathrm{O} \times \mathrm{D}$ where $\mathrm{O}$ is a daily sale of stock, $\mathrm{D}$ is a stock level. But the approaches to determine the daily sale of drug stock from the WPC warehouse and the stock level must be different (Fig.).

Different aspects of stock setting determine a set of groups of drug stock in the pharmacy distribution. In social terms, the stock should have the following groups: quarantine-prevention $\left(\mathrm{T}_{\mathrm{k}-\mathrm{p}}^{s}\right)$; current $\left(T_{c}^{s}\right)$; buffer $\left(T_{b}^{s}\right)$; reserve $\left(T_{r}^{s}\right)$. Thus, taking into account the social parameters the total stock level will be:

$$
\mathrm{T}^{\mathrm{s}}=\mathrm{T}_{\mathrm{q}-\mathrm{p}}^{s}+T_{c}^{s}+T_{b}^{s}+T_{r}^{s}
$$

Such limits and grouping of stock are explained by the peculiarities of processes and activities performed by the WPC to meet the customers' needs. In financial terms, the stock has the following groups: transport (to the WPC warehouse) $\left(\mathrm{T}_{\mathrm{tr}}^{\mathrm{f}}\right)$, quarantine-prevention $\left(\mathrm{T}_{\mathrm{k}-\mathrm{p}}^{f}\right)$; current $\left(T_{c}^{f}\right)$; buffer $\left(T_{b}^{f}\right)$; transport (from the WPC warehouse to the pharmacy) $\left(T_{t}^{f}\right)$; as receivables $\left(T_{\mathrm{r}}^{f}\right)$. Thus, taking into account the financial parameters the total stock level at the WPC will be:

$$
\mathrm{T}^{\mathrm{f}}=\mathrm{T}_{\mathrm{tr}}^{\mathrm{f}}+\mathrm{T}_{\mathrm{k}-\mathrm{p}}^{f}+T_{c}^{f}+T_{b}^{f}+T_{t}^{f}+T_{\mathrm{r}}^{f} .
$$

A specific feature of the stock level calculation taking into account the social aspect is a personal approach to the customer servicing that requires to consider the drug status per each product line group. This approach affects both the stock level and calculation of a daily sale.

The social component of the quarantine-prevention stock is made in order to prepare medications for the customer's order kitting. According to the requirements of Good Storage Practice (GSP) [2], all medications at the WPC warehouse must be checked. If a medication does not comply with set quality requirements, such medication must be destroyed or returned to a supplier. If a sale permit is obtained, the medication becomes a stock, is recorded in balance account 'Goods' and transferred to be prepared for the storage area. The preparation stock standard includes the following activities: drug stock transfer from the quarantine area to the acceptance area, drug recording, transfer to the storage area, placing in the storage area. This standard is determined by timing observation and is the same for all drug line groups.

The social component of the current stock of medications at the WPC warehouse is made to ensure the uninterrupted meeting of customer's demand and is calculated as per the product line group. In case of the reliable supply (the rate of the supplier's reliability approaches 1), the current stock is calculated according to the formula:

$$
T_{c}^{s}=\frac{D}{K_{j \mathrm{del}}},
$$

where: $\mathrm{D}$ is the number of days in the previous period (month); $\mathrm{K}_{\mathrm{jdel}}$ is the number of deliveries of the $\mathrm{j}$-drug line group during the period.

The social component of the buffer stock is made to meet the customer's demand in case of an interruption of drug supply to the WPC warehouse. Its level must be calculated taking into account the supplier's reliability rate according to the formula:

$$
T_{b}^{s} j=\frac{\sum V_{j i} \times\left(1-H_{i}^{n}\right) \times T_{i}^{n}}{V_{j}},
$$

where: $V_{j i}$ is delivery of the $\mathrm{j}$-drug line group by the $\mathrm{i}$-th supplier, UAH; $V_{j}$ is delivery of the j-drug line group by all suppliers, $\mathrm{UAH} ; \mathrm{T}_{\mathrm{i}}^{\mathrm{n}}$ is the delivery time of the $\mathrm{j}$-drug line group by the $\mathrm{i}$-th supplier in case of the reliable supply.

$H_{i}^{\mathrm{n}}$ is the supplier's reliability rate of the i-th supplier calculated according to the formula [3]:

$$
H_{n}=\left(1-P_{i}^{1}\right) \times\left(1-P_{i}^{2}\right) \times\left(1-P_{i}^{3}\right) \times\left(1-P_{i}^{4}\right),
$$

where: $p_{i}^{1}$ is probability of failure to meet transport terms by the $\mathrm{i}$-th supplier; $p_{i}^{2}$ is probability of failure to meet the delivery time; $p_{i}^{3}$ is probability of failure to meet the requirements of accompanying documents execution; $p_{i}^{4}$ is probability of noncompliance of accompanying documents information with the actual state. 
Pharmacy Location Segmentation

\begin{tabular}{|c|l|c|c|}
\hline Group & \multicolumn{1}{|c|}{ Characteristics of a pharmacy } & $\begin{array}{c}\text { The share of relatively } \\
\text { expensive medications, } \%\end{array}$ & $\begin{array}{c}\text { The share of relatively } \\
\text { cheap medications, } \%\end{array}$ \\
\hline A & Popular (in the populated areas) & $25-35$ & $<10$ \\
\hline B & Mixed & $\leq 25$ & $10-20$ \\
\hline C & Bedroom (in a bedroom district) & $\leq 20$ & 25 \\
\hline
\end{tabular}

The social component of the reserve stock is made at WPC warehouses for unforeseen demand fluctuations ( $\mathrm{T}_{\mathrm{uf}}^{\mathrm{s}}$ ) and seasonal demand fluctuations $\left(T_{s f}^{s}\right)$.

It is appropriate to calculate the social component of the reserve stock according to the formula:

$$
\mathrm{T}_{\mathrm{r}}^{\mathrm{s}}=T_{u f}^{s}+T_{s f}^{s} \text {. }
$$

The WPC must always have the drug reserve stock for unforeseen demand fluctuations at the warehouse, it should be sufficient for a period between two subsequent deliveries, it is calculated according to the formula (3). The drug reserve stock for seasonal demand fluctuations should be calculated based on the estimated trends of the seasonal increase in sale of this or that medication in previous years.

In social terms of stock management, the level of a daily sale of medications from the WPC warehouse should be made as per the product line group based on the pharmacy location segmentation. The pharmacy location segmentation methodology was proposed by Slavych-Prystupa O.S. [4] (Tab. 1).

The daily sale of medications from the WPC warehouse taking into account the social component in periods with no seasonal demand fluctuations is calculated as follows:

$$
\mathrm{O}_{\mathrm{j} 3}^{\mathrm{s}}=\sum_{n=1}^{3}\left(O_{\mathrm{jcn}}^{s}+O_{j \text { uf n }}^{\mathrm{s}}\right),
$$

where $\mathrm{n}$ is a segment of pharmacies; group $\mathrm{A}$ is 1; group $\mathrm{B}$ is 2 ; group $\mathrm{C}$ is $3: j$ is the number of drug line groups; $O_{j \mathrm{cn}}^{\mathrm{s}}$ is a daily sale of the current stock of the j-drug line group for pharmacies of the n-th segment, UAH, calculated according to the formula:

$$
\mathrm{O}_{\mathrm{jcn}}^{\mathrm{s}}=\sum_{j=1}^{N} \mathrm{k}_{\mathrm{j}} \times \frac{O_{j n}^{d-1}}{D},
$$

where: $\mathrm{k}_{\mathrm{j}}$ is a change in drug sale in the $\mathrm{n}$-th segment of pharmacies; it is calculated based on the trend of changes in frequency of prescribing drugs in nosology; $O_{j n}^{d-1}$ is the volume of sales of the $j$-drug line group in the n-th segment of pharmacies in the previous period (month), thousands UAH; $D$ is the number of days in the previous period; $\mathrm{O}_{\mathrm{juf} n}^{\mathrm{s}}$ is a daily sale of the reserve stock of the j-drug line group in the n-th segment of pharmacies in case of unforeseen demand fluctuation, UAH.

It has been suggested to use the ABC-VEN analysis to determine the stock for unforeseen demand fluctuation. The matrix of drug grouping according to this method is described in Tab. 2.
Table 2

The matrix of drug grouping according to the ABC-VEN analysis

\begin{tabular}{|c|c|c|c|}
\hline Category of stock & V & E & N \\
\hline A & AV & AE & AN \\
\hline B & BV & BE & BN \\
\hline C & CV & CE & CN \\
\hline
\end{tabular}

Table 3

The volume of the drug reserve stock suggested for unforeseen demand fluctuation

\begin{tabular}{|c|c|c|}
\hline Group & $\begin{array}{c}\text { Requirement } \\
\text { condition }\end{array}$ & $\begin{array}{c}\text { Reserve stock } \\
\text { requirement, } \%\end{array}$ \\
\hline $\mathrm{AV}, \mathrm{AE}, \mathrm{BV}, \mathrm{CV}$ & $\mathrm{P}=1$ & 100 \\
\hline $\mathrm{AN}, \mathrm{BE}, \mathrm{CE}$ & $\mathrm{P}=0.95$ & 95 \\
\hline $\mathrm{BN}, \mathrm{CN}$ & $\begin{array}{c}\text { Based on the stock } \\
\text { shortage analysis }\end{array}$ & $10-15$ \\
\hline
\end{tabular}

The requirements to the volume of drug reserve stock at the WPC for unforeseen demand fluctuation as suggested based on the experts survey are given in Tab. 3 .

In case of seasonal fluctuations in drug sale the daily volume of sale from the warehouse is calculated according to the formula:

$$
\mathrm{O}_{\mathrm{j} 3}^{\mathrm{s}}=\sum_{n=1}^{3}\left(O_{\mathrm{jcn}}^{s}+O_{j \mathrm{uf} \mathrm{n}}^{\mathrm{s}}+O_{j \mathrm{sf} \mathrm{n}}^{\mathrm{s}}\right),
$$

where: $O_{j \text { sf n }}^{s}$ is a daily sale of the j-drug line group for pharmacies of the n-th segment; it is calculated according to the formula:

$$
O_{j \mathrm{sfn}}^{\mathrm{s}}=\frac{V_{j \mathrm{sf} \mathrm{n}}}{\mathrm{T}} \times I,
$$

where: $V_{j \text { sf }}$ is the volume of sale of the j-drug line group for pharmacies of the $\mathrm{n}$-th segment during the seasonal demand fluctuation, UAH; I is the yearly price increase index; $T$ is duration of the period when important demand fluctuations are observed, days.

Thus, considering social parameters, it is advisable to calculate the drug stock level in pharmacy distribution as follows:

$$
\begin{gathered}
H_{H}^{s}=\left(T_{q-p}^{s}+T_{c}^{s}+T_{b}^{s}+T_{r}^{s}\right) \times \\
\times\left(O_{j \mathrm{cn}}^{\mathrm{s}}+O_{j u f \mathrm{n}}^{s}+O_{j \mathrm{sf} \mathrm{n}}^{\mathrm{s}}\right) .
\end{gathered}
$$


Differences between the traditional approach and the approach suggested to drug stock setting in pharmacy distribution

\begin{tabular}{|c|c|c|c|}
\hline \multirow{3}{*}{ Parameter } & \multicolumn{3}{|c|}{ Approaches to drug stock setting in pharmacy distribution } \\
\hline & \multirow[b]{2}{*}{ traditional } & \multicolumn{2}{|c|}{ based on the logistic service personalization } \\
\hline & & $\begin{array}{l}\text { taking into account financial } \\
\text { parameters }\end{array}$ & $\begin{array}{l}\text { taking into account social } \\
\text { parameters }\end{array}$ \\
\hline Objective & $\begin{array}{l}\text { to minimize money costs for } \\
\text { building up a stock }\end{array}$ & $\begin{array}{l}\text { to minimize money costs for } \\
\text { building up a stock }\end{array}$ & $\begin{array}{l}\text { Appropriate fulfillment of the } \\
\text { customer's needs }\end{array}$ \\
\hline Principles & Cost minimization & Cost minimization & $\begin{array}{l}\text { Economical efficiency } \\
\text { Social responsibility }\end{array}$ \\
\hline Priority aspect & Financial & Financial & Social \\
\hline Types of stocks & Transport, current, reserve & $\begin{array}{l}\text { Transport, quarantine- } \\
\text { prevention, current, buffer, } \\
\text { reserve, transport, money }\end{array}$ & $\begin{array}{l}\text { Quarantine-prevention, } \\
\text { current, buffer, reserve }\end{array}$ \\
\hline Conditions of use & - & 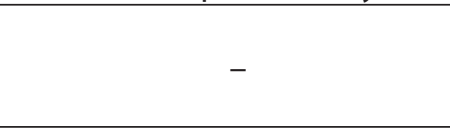 & $\begin{array}{l}\text { A unique information space } \\
\text { for partners within pharmacy } \\
\text { logistic and supply chains }\end{array}$ \\
\hline $\begin{array}{l}\text { Methodological } \\
\text { framework }\end{array}$ & \multicolumn{2}{|c|}{$\begin{array}{l}\text { Methodology for determining the quota for current assets. - } \\
\text { Kyiv : Ministry of Industrial Policy of Ukraine, } 1998 \text { [5] }\end{array}$} & $\begin{array}{l}\text { GDP Requirements [1] } \\
\text { GSP Requirements [2] }\end{array}$ \\
\hline Users & Financial Department & Financial Department & Logistics Department \\
\hline
\end{tabular}

The studies have allowed determining differences between the traditional approach and the approach suggested to drug stock setting at the WPC (Tab. 4).

CONCLUSIONS

1. This paper has shown that stock setting in pharmacy distribution needs special attention due to a number of causes.

2. The methodology of stock setting at the WPC must be based on the social responsibility principle requiring distributors to develop personal logistic solutions to meet the customer's needs and guarantee the physical availability of medications, especially of vital drugs. These re- quirements must be taken into account when setting the stock in pharmacy distribution.

3. In social terms, the drug stock should contain the following groups: quarantine-prevention, current, buffer, reserve.

4. In order to make personal logistic solutions for the customer service and determine the volume of a daily sale for the social component of stock setting in pharmacy distribution, the $\mathrm{ABC}-\mathrm{VEN}$ analysis has been suggested; it allows to differentiate the drug stock line at the WPC in terms of their importance not only to provide the profitability of the WPC, but also to take into account their importance for customers.

\section{REFERENCES}

1. Лікарські засоби. Належна практика дистрибуиї. СТ-Н МОЗУ 42-5.0:2014. - К.: МОЗУ, 2014. - 51 c.

2. Лікарські засоби. Належна практика зберігання. СТ-Н МОЗУ 42-5.0:2014. - К.: МОЗУ, 2014. - 23 с.

3. Посилкіна О.В. // Управління, економіка та забезпечення якості в фармачії. - 2015. - №1 (39). - С. 80-84.

4. Славич-Приступа А.С. Практический маркетинг для аптек. - М.: Ремедиум, 2005. - 138 с.

5. Methodology for defining the quota for current assets. - K.: Ministry of Industrial Policy of Ukraine, 1998. - 5 c.

\section{РОЗРОБКА МЕТОДИЧНИХ ЗАСАД НОРМУВАННЯ ЗАПАСІВ ЛІКАРСЬКИХ ЗАСОБІВ У ФАРМАЦЕВТИЧНІЙ ДИСТРИБУЦІї \\ О.В.Посилкіна, В.Г.Котлярова, Ю.Є.Новицька}

Ключові слова: індивідуалізація; логістичний сервіс; клієнт; соціальна відповідальність Доведено, що застосування традиційного підходу до нормування запасів ЛЗ у фрармацевтичній дистрибуції призводить, скоріше, до визначення рівня іммобілізованих грошових коштів на створення запасів та не враховує потреб, очікувань, особливостей клієнтів та різної соціальної значущості окремих фрармакотерапевтичних груп ЛЗ. Методологія, на якій грунтується існуючий підхід до нормування запасів, не відповідає сучасним вимогам щодо належного рівня обслуговування клієнтів. Тому виникла необхідність удосконалення підходу до нормування запасів лікарських засобів у фрармацевтичній дистрибуції. Соціальна відповідальність фрармацевтичного бізнесу передбачає необхідність застосування не тільки економічних, але й соціальних параметрів при нормуванні запасів ЛЗ. 3 точки зору соціального аспекту завдання нормування запасів полягає у визначенні переліку ЛЗ та їх обсягів, що повинні бути на складі для належного забезпечення потреб клієнтів. 3 точки зору соціального аспекту запаси повинні розподілятися на такі види: карантинно-підготовчий, поточний, буфрерний, 
страховий. Обсяг одноденної реалізації розраховується з врахуванням обсягів реалізації в разі відсутності сезонних коливань з врахуванням тенденції до зміни частоти призначення ЛЗ за нозологією; страхового запасу ЛЗ на випадок непередбаченого коливання попиту; у період сезонного коливання попиту. 3 метою забезпечення високого рівня надійності обслуговування клієнтів для визначення рівня страхового запасу пропонується застосовувати ABC-VEN аналіз.

\section{РАЗРАБОТКА МЕТОДИЧЕСКИХ ОСНОВ НОРМИРОВАНИЯ ЗАПАСОВ ЛЕКАРСТВЕННЫХ СРЕДСТВ В ФАРМАЦЕВТИЧЕСКОЙ ДИСТРИБУЦИИ \\ О.В.Посылкина, В.Г.Котлярова, Ю.Е.Новицкая}

Ключевые слова: индивидуализация; логистический сервис; клиент; социальная ответственность

Доказано, что применение традиционного подхода к нормированию запасов ЛС в фрармацевтической дистрибуции приводит, скорее, к определению уровня иммобилизованных денежных средств на создание запасов и не учитывает потребностей, ожиданий, особенностей клиентов и разной социальной значимости отдельных фрармакотерапевтических групп ЛС. Методология, на которой основывается существующий подход к нормированию запасов, не отвечает современным требованиям относительно надлежащего уровня обслуживания клиентов. Поэтому возникла необходимость усовершенствования подхода к нормированию запасов лекарственных средств в фрармацевтической дистрибуции. Социальная ответственность фрармацевтического бизнеса предусматривает необходимость применения не только экономических, но и социальных параметров при нормировании запасов ЛС. С точки зрения социального аспекта задание нормирования запасов заключается в определении перечня ЛС и их объемов, что должны быть на складе для надлежащего обеспечения потребностей клиентов. С точки зрения социального аспекта запасы должны распределяться на такие виды: карантинно-подготовительный, текущий, буферный, страховой. Объем однодневной реализации рассчитывается с учетом объема реализации: в случае отсутствия сезонных колебаний с учетом тенденции к изменению частоты назначения ЛС за нозологией; страхового запаса ЛС на случай непредвиденного колебания спроса; в период сезонного колебания спроса. С целью обеспечения высокого уровня надежности обслуживания клиентов для определения уровня страхового запаса предлагается применять ABC-VEN анализ. 